\title{
Immune response of mice to Echinococcus multilocularis infection after therapy with amphotericin B colloidal dispersion
}

\author{
J. PORUBCOVÁ ${ }^{1}$, E. DVOROŽŇÁKOVÁ ${ }^{1}$, Z. ŠEVČÍKOVÁ ${ }^{2}$
}

\begin{abstract}
${ }^{1}$ Parasitological Institute of the Slovak Academy of Sciences, Hlinkova 3, 04001 Košice, Slovak Republic, E-mail: dvoroz@saske.sk; ${ }^{2}$ Institute of Pathological Anatomy, University of Veterinary Medicine, Komenského 73, 041 81 Košice, Slovak Republic
\end{abstract}

\begin{abstract}
Summary
The effect of amphotericin B colloidal dispersion (ABCD) on selected immunological parameters and growth of the larval cysts in mice infected intraperitoneally with Echinococcus multilocularis protoscoleces was observed. ABCD was administered at a dose $10 \mathrm{mg} / \mathrm{kg}$ body weight twice a week from week 5 to 10 post infection (p.i.). The Echinococcus infection suppressed the proliferative response of splenic T lymphocytes to nonspecific mitogen concanavalin A throughout almost the whole course of the experiment and ABCD administration did not affect this inhibittion. The increase in the proliferative response of B lymphocytes to lipopolysaccharide was found in infected mice with $A B C D$ treatment from week 6 to 10 p.i. ABCD induced a significant rise of the splenic CD4 T cell subpopulation in infected mice only on week 6 p.i. The CD8 T subpopulation was not influenced by the therapy. The level of serum Th1 cytokine IFN- $\gamma$ in infected and ABCD treated mice was elevated only at week 8 p.i., while the level of serum Th2 cytokine IL-5 was not influenced by the therapy. The ABCD treatment inhibited the IFN- $\gamma$ production by splenocytes in vitro from week 6 to 10 p.i. On the contrary, the IL-5 production in vitro was stimulated at weeks 8 and 12 p.i. None antiparasitic effect of ABCD on larval growth was determined.

Results suggest that amphotericin B colloidal dispersion did not affect the inhibited Th1 immune response after parasite infection. On the contrary, ABCD advanced the Th2 immune response development, which allows the progressive growth of the parasite.
\end{abstract}

Key words: Echinococcus multilocularis; amphotericin B; mice; T and B lymphocytes; IL-5, IFN- $\gamma$; superoxide anion

\section{Introduction}

Alveolar echinococcosis caused by the metacestode stage of Echinococcus multilocularis is a serious, life-threaten- ing parasitozoonosis, lethal in $90 \%$ of untreated patients in 10 years after the diagnosis (Amman \& Eckert, 1996). The disease is characterised by an infiltrative, tumour-like growth of the E. multilocularis metacestode, affecting the liver of intermediate hosts such as small mammals or man (Thompson, 1995). A surgical extirpation of cysts is not always successful owing to their ability to form metastatic foci (Schantz, 2002). The chemotherapy of alveolar echinococcosis with available anthelmintics (benzimidazoles) has only a parasitostatic effect and is therefore performed over many years, often through the patient's life (Reuter et al., 2000). This brings the risk of adverse reactions to the drugs, among which gastrointestinal disturbances, reversible alopecia, hepatitis, proteinuria, neurological symptoms are the most frequent, there may also be a strong teratogenic effect (Capece et al., 2003). New chemotherapeutic strategies against E. multilocularis are urgently needed for patients who do not tolerate or do not respond to benzimidazoles. Reuter et al. (2003a,b) recorded a suppression of metacestode's growth after the alternative treatment with amphotericin B in an in vitro tissue culture model and also in human patients with alveolar echinococcosis.

Amphotericin B (AMB) is a macrolide polyene antibiotic, a natural product of Streptomyces nodosus (Ellis, 2002). $\mathrm{AMB}$ is an effective antifungal agent and an antiparasitic drug effective against organisms containing ergosterols in their membranes (Brajtburg \& Bolard, 1996). The AMB treatment is limited by its possible serious side effect, including nephrotoxicity, which can result in irreversible renal failure (Clements \& Peacock, 1990). Drug toxicity can be reduced by the incorporation of AMB into a lipid-based carrier system, which alters the pharmacokinetics and tissue distribution of the drug (Hiemenz \& Walsh, 1996). Liposome-based drugs - liposomal AMB (Ambisome), AMB lipid complex (Abelcet), and AMB colloidal dispersion (Amphocil) allow larger doses to be administered and thereby increase its efficacy (Joly et al., 1994; Clemons et al., 
2001; Hann \& Prentice, 2001). Since the primary site of $E$. multilocularis metacestode development in intermediate host is the liver (Amman \& Eckert, 1996), Amphocil affinity to liver could be advantageous in therapy of alveolar echinococcosis.

The results of treatment might be affected by the immunological status of the host, susceptibility and the stage of infection (Heath, 1995). The E. multilocularis infection induces in the host organism parasite-specific cellular and also humoral immune responses. A retrogressive, as well as progressive course of the disease correlates with stadium specific granuloma cell composition and antigen-specific $\mathrm{T}$ cell response (Bresson-Hadni et al., 1990; Emery et al., 1996). Activation of the Th1 subpopulation of CD4 T lymphocytes is connected with control of infection (Manfras et al., 2004). The Th2 reversion contributes to longtime manifestation of E. multilocularis infection in humans (Sturm et al., 1995). The E. multilocularis metacestode can specifically manipulate the balance between Th1 and Th2 response leading to reduced effectiveness of the immune response (Kilwinski et al., 1999; Vuitton, 2003).

The AMB distribution in vivo and its efficacy can be modified by several factors - the drug's ability to bind to selected molecules from plasma, to bind to tissues and organs, and the ability of vesicles of differing sizes to traverse the endothelium (Brajtburg \& Bolard, 1996). With re-gard to this fact and the modification of the immune sys-tem after AMB treatment this work arose with the aim to observe and verify an antiparasitic effect of AMB therapy and also AMB impact on the development of the cellular immune response under in vivo conditions.

The aim of this study was to investigate the effect of amphotericin B colloidal dispersion (Amphocil) on the larval development of E. multilocularis and the immune response in the murine model of alveolar echinococcosis.

\section{Materials and Methods}

\section{Infection}

E. multilocularis metacestode infection (strain gifted from Department of Medical Parasitology, Clinical Institute of Hygiene and Medical Microbiology, Medical University of Vienna, Austria) was maintained in our laboratory by intraperitoneal passage through Mongolian jirds Meriones unguiculatus. Protoscoleces were isolated from vesicular cysts 4 months post infection (p.i.). Parasite material was cut into pieces in sterile RPMI 1640 medium (Sigma-Aldrich, Germany) supplemented with antibiotics $100 \mathrm{U} / \mathrm{ml}$ penicillin and $100 \mu \mathrm{g} / \mathrm{ml}$ streptomycin (Sigma-Aldrich, Germany) and passed through a Cell Dissociation Sieve Tissue Grinder Kit using apertures ranging from 380 to $45.7 \mu \mathrm{m}$ (Sigma-Aldrich, Germany). Protoscoleces collected after the last filtration were counted and maintained in RPMI until use.

\section{Experimental design}

The experiments were carried out on pathogen-free inbred male BALB/c mice $(n=132)$ weighing $20-25$ g. Mice were kept under a 12-h light/dark regime at room temperature $\left(21 \pm 3^{\circ} \mathrm{C}\right)$ and $50-60 \%$ relative humidity on a commercial diet and water. The experimental protocol was approved by the Parasitological Institute Animal Care Committee. Animals were divided randomly into four groups as follows: Group 1 was uninfected and untreated (control), mice in Group 2 were uninfected and treated with amphotericin B colloidal dispersion - ABCD (Amphocil, Torrex Pharma GmBh, Czech Republic) application intravenously into the tail vein twice a week at the dose of $10 \mathrm{mg} / \mathrm{kg}$ of body weight starting at week 5 up to week 10 p.i. Mice in Groups 3 and 4 were infected intraperitoneally with $5000 \mathrm{E}$. multilocularis protoscoleces per mouse. Group 3 had no treatment, in Group 4 ABCD was applied as above. The therapeutical regime was taken from an effective benzimidazole therapy in our previous experiments.

Samples of blood, spleen and peritoneal macrophages were obtained on the following weeks: 0 (prior infection), 2, 4, $6,8,10,12,14,18,22$ and 26 p.i. from all groups (three mice per experimental day).

\section{Efficacy of treatment}

The antiparasitic effect of ABCD therapy was evaluated according to the cyst growth in infected mice. E. multilocularis cysts were collected on the stated days from sacrificed mice in groups 3, 4 and parasite biomass was weighed and then mean value \pm S.D. was obtained $(n=3)$.

\section{T and B lymphocyte proliferation assay}

The splenic cells were aseptically isolated, washed twice with phosphate buffered saline (PBS) (pH 7.2) and finally with RPMI 1640 medium (Sigma-Aldrich, Germany). The contamination of erythrocytes was removed by lysis in hypotonic solution $\left(0.85 \% \mathrm{NH}_{4} \mathrm{Cl}\right)$ and lymphocytes were resuspended to a final concentration of $5 \times 10^{6}$ cells $/ \mathrm{ml}$. The proliferation assay was carried out in 96 wells plates (Nunc, Denmark) and cells were incubated in RPMI 1640 medium $(100 \mu \mathrm{l})$ containing $10 \%$ bovine fetal serum, 100 $\mathrm{U} / \mathrm{ml}$ penicillin, and $100 \mu \mathrm{g} / \mathrm{ml}$ streptomycin. Polyclonal activators Concanavalin A (Con A) (T cells) and lipopolysaccharide (LPS) (B cells) (Sigma-Aldrich, Germany) at the final concentration $2 \mu \mathrm{g} / \mathrm{ml}$ were added in a dose 100 $\mu \mathrm{l}$ to the cell suspensions and incubated at $37^{\circ} \mathrm{C}$ in $5 \%$ $\mathrm{CO}_{2}$ and $85 \%$ humidity for 72 hours. The stimulation index (SI) was determined using a colorimetric assay where $20 \mu \mathrm{l}$ aliquots of 3,4-dimethylthiazolyl 2,5-diphenyltetrazolium bromide (Sigma-Aldrich, Germany) $(0.1 \%$ solution) were added to the cell pellets, incubated for $4 \mathrm{~h}$ at $37^{\circ} \mathrm{C}$ and $5 \% \mathrm{CO}_{2}$ followed by centrifugation of the plates at $800 \times \mathrm{g}$ for $5 \mathrm{~min}$. Reaction was terminated with dimethylsulfoxide (Sigma-Aldrich, Germany) (200 $\mu \mathrm{l} /$ cell sample) and samples were read using an ELISA plate reader (Multiskan Plus, Labsystem, Finland) at a wavelength of $540 \mathrm{~nm}$ and $630 \mathrm{~nm}$. The stimulation indices (SI) were calculated according to the formula of Pagé et al. (1988): $\mathrm{SI}=\mathrm{E}_{540}-\mathrm{E}_{630}$ (stimulated cells)/ $\mathrm{E}_{540}-\mathrm{E}_{630}$ (unstimulated cells). 
Proliferative responses were measured separately for lymphocytes isolated from each mouse per group.

Number of CD4+ and CD8+T cells

Lymphocytes isolated from the mice spleens and depleted of erythrocytes were resuspended in PBS ( $\mathrm{pH}$ 7.2) at a final concentration $1 \times 10^{6}$ cells $/ \mathrm{ml}$. After incubation of cell samples with directly-labelled rat anti-mouse CD4+ fluorescein isothiocyanate conjugated and rat anti-mouse CD8+ phycoerythrin conjugated monoclonal antibodies (BD Biosciences PharMingen, Belgium) at the concentration $0.4 \mu \mathrm{g} / 10^{6}$ cells at $4^{\circ} \mathrm{C}$ for $30 \mathrm{~min}$, cells were then washed three times with PBS containing $0.1 \% \mathrm{NaN}_{3}$ and analysed by the Flow cytometry method. Data for $10^{4}$ cells/sample, falling within forward and side scatter gates set specific for lymphocytes, were collected with the FACScan flow cytometer (Becton Dickinson Biosciences, Germany). All data files were analysed with CellQuest software. Cells from each mouse per group were analysed individually. The final numbers of both cell populations were calculated as proportion from the total isolated lymphocytes per spleen/mouse.

\section{Concentration of IFN- $\gamma$ and IL-5}

For cytokine production in vitro, splenocyte suspensions $\left(10^{7} / \mathrm{ml} \mathrm{RPMI}\right)$ were distributed to flat bottom 96-well plates (Nunc, Denmark). To each well containing splenocyte suspension $(100 \mu \mathrm{l} /$ well) (set in triplicates for each variant) $100 \mu \mathrm{l}$ of Concanavalin A (Sigma-Aldrich, Germany) $(1 \mu \mathrm{g} / 100 \mu \mathrm{l}$ RPMI $)$ were added. Cultures were kept at $37^{\circ} \mathrm{C}$ and $5 \% \mathrm{CO}_{2}$ and supernatants were harvested after $24 \mathrm{~h}$ and stored at $-80^{\circ} \mathrm{C}$ prior cytokine determinations. The capture ELISA was employed to determine the concentration of cytokines IFN- $\gamma$ and IL- 5 in the serum of mice from all the experimental groups and from the in vitro splenocytes using the method of Soltýs and Quinn (1999). IFN- $\gamma$ and IL-5 were used as marker cytokines for the Th1 and Th2 responses, respectively. Two pairs of cytokinespecific monoclonal antibodies were used: R4-6A2 and XMG1.2 for IFN- $\gamma$ and TRFK5 and TRF4 for IL-5 (BD Biosciences PharMingen, Belgium). Results were expressed as $\mathrm{pg} / \mathrm{ml}$ using murine recombinant IFN- $\gamma$ and IL-5 (BD Biosciences PharMingen, Belgium) as standards. The detection limit of the assay for the both cytokines was 40 $\mathrm{pg} / \mathrm{ml}$.

\section{Superoxide anion assay}

Generation of extracellular superoxide anion $\left(\mathrm{O}_{2}^{-}\right)$from peritoneal macrophages was assayed as superoxide dismutase (SOD)-inhibitable reduction of ferricytochrome $\mathrm{C}$ with and without stimulation with phorbol myristate acetate (PMA) (Hrčková \& Velebný, 1997). Peritoneal exudate cells were aseptically harvested in RPMI 1640 (Sigma-Aldrich, Germany) and diluted so as to obtain a concentration of $1 \times 10^{6}$ cells $/ \mathrm{ml}$. One $\mathrm{ml}$ of cell suspension was added to each well using 24-well plates (Falcon, France) and incubated at $37^{\circ} \mathrm{C}$ in $5 \% \mathrm{CO}_{2}$ and $85 \%$ humidity for $2 \mathrm{~h}$. Non-adherent cells were removed by washing with ice-cold Earls Balanced Salt Solution (EBSS) (pH 7.2). The reaction was carried out in $0.5 \mathrm{ml} /$ well of $160 \mu \mathrm{M}$ ferricytochrome $\mathrm{C}$ (Sigma-Aldrich, Germany) in EBSS. In control wells the reaction was immediately blocked by $300 \mu \mathrm{g} \mathrm{SOD} / 10 \mu \mathrm{l}$ in EBSS. Ten $\mu$ l of PMA in ethanol was used for the stimulation of cells for respiratory burst. Cells were incubated at $37^{\circ} \mathrm{C}$ in $5 \% \mathrm{CO}_{2}$ and $85 \%$ humidity for $2 \mathrm{~h}$ and supernatant from wells was collected to the cooled plastic tubes, then vortexed at $170 \times \mathrm{g}$ for $3-4 \mathrm{~min}$ to remove cells. The optical density (OD) at $550 \mathrm{~nm}$ was measured in aliquots of supernatant for each well in a 96-well plate reader (Multiscan Plus, Labsystems, Finland). Cell-protein concentration in each well was assessed by the Bradford protein microassay, using standard reagent and bovine serum albumin as the protein standard (BioRad, UK) and the OD was read at $595 \mathrm{~nm}$. The amount of $\mathrm{O}_{2}^{-}$produced was calculated from the difference in OD in reactions blocked by SOD and without SOD and the resulting value was used to calculate nmol of $\mathrm{O}_{2}^{-}$produced according to the formula: nmol $\mathrm{O}_{2}^{-}=(\mathrm{OD} / 6.3) \times 100$ and determinated for $1 \mathrm{mg}$ of cell proteins.

\section{Statistical evaluation}

Statistical differences were assessed using one-way ANOVA, followed by post hoc Tukey's test (a value of $\mathrm{P}$ $<0.05$ was considered significant), which allowed comparison between each two groups at each time point. The analyses were performed using the Statistica 6.O (Stat Soft, Tulsa, USA) statistical package.

\section{Results}

\section{Effect of treatment on cyst growth}

The efficacy of ABCD treatment was considered in relation to the cyst weights (g) (Tab.1). The growth of the parasite larval cysts was slow till week 6 p.i, a rapid metacestode development was observed from week 8 to 26 p.i. No significant reduction of the cyst weight was noticed in the group of infected mice with ABCD therapy in comparison to the infected nontreated group during the whole ti-

Table 1. The weight of E. multilocularis cysts in mice after ABCD therapy

\begin{tabular}{ccc}
\hline $\begin{array}{c}\text { Week } \\
\text { p.i. }\end{array}$ & $\begin{array}{c}\text { Infected } \\
\text { mean } \pm \text { S.D.(g) }\end{array}$ & $\begin{array}{c}\text { Infected and treated with ABCD } \\
\text { mean } \pm \text { S.D. }(\mathrm{g})\end{array}$ \\
\hline 2 & $0.24 \pm 0.20$ & $0.28 \pm 0.37$ \\
4 & $0.58 \pm 0.08$ & $0.49 \pm 0.18$ \\
6 & $1.44 \pm 0.77$ & $0.83 \pm 0.33$ \\
8 & $2.05 \pm 0.63$ & $2.05 \pm 0.75$ \\
10 & $3.97 \pm 2.40$ & $3.66 \pm 0.31$ \\
12 & $4.03 \pm 0.60$ & $4.40 \pm 0.26$ \\
14 & $5.71 \pm 1.55$ & $4.86 \pm 0.15$ \\
18 & $8.35 \pm 1.91$ & $9.07 \pm 0.93$ \\
22 & $7.62 \pm 0.55$ & $9.66 \pm 2.21$ \\
26 & $9.90 \pm 1.70$ & $11.8 \pm 0.90$ \\
\hline
\end{tabular}




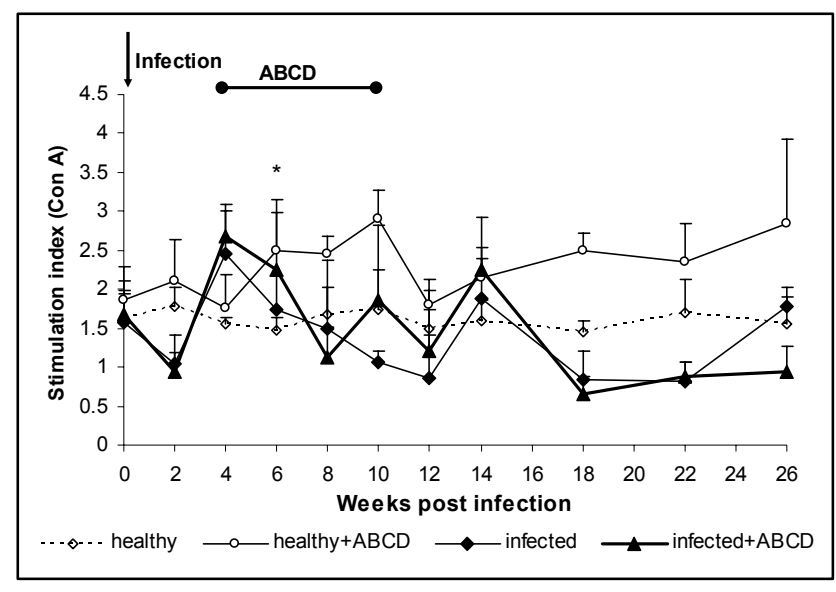

Fig. 1. Proliferative response of T lymphocytes to concanavalin A (Con A) in mice infected with E. multilocularis and after ABCD therapy. Data for each time-point are expressed as mean stimulation index \pm S.D. $(\mathrm{n}=3) . *(\mathrm{P}<0.05)$ significant differences between uninfected mice and uninfected mice with ABCD therapy

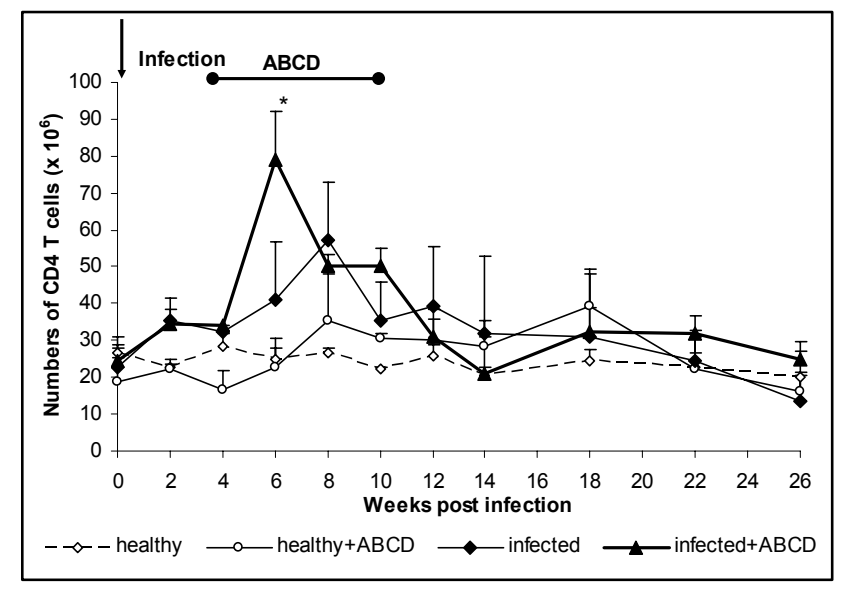

Fig. 3. Number of spleen CD4 T cells in mice infected with $E$. multilocularis and after ABCD therapy. Data for each time-point are expressed as mean value \pm S.D. $(n=3)$. $*(P<0.05)$ significant difference between infected mice and infected mice with $\mathrm{ABCD}$ therapy

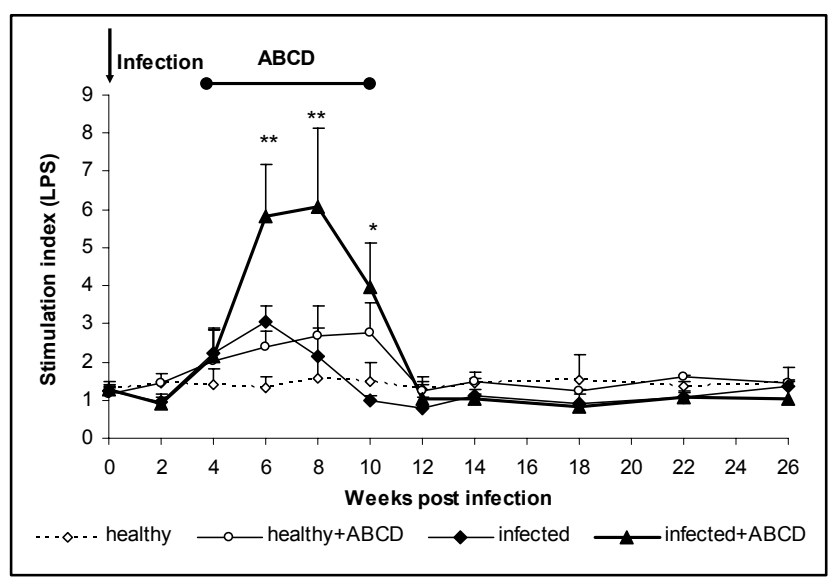

Fig. 2. Proliferative response of B lymphocytes to lipopolysaccharide (LPS) in mice infected with E. multilocularis and after ABCD therapy. Data for each time-point are expressed as mean stimulation index \pm S.D. $(\mathrm{n}=3) . *(\mathrm{P}<0.05), * *(\mathrm{P}<0.01)$ significant differences

between infected mice and infected mice with $\mathrm{ABCD}$ therapy

me of the drug application, even after the end of treatment. Proliferative response of $T$ and $B$ lymphocytes

The proliferative response of spleen $T$ cells to nonspecific mitogen Concanavalin A (ConA) was examined in all experimental groups of mice and was expressed as a stimulation index (SI) (Fig. 1). In comparison with the control group of mice, ABCD therapy stimulated the proliferative response of $\mathrm{T}$ cells only in healthy mice, from week 6 to 10 , with the significant increase on week $6(\mathrm{P}<0.05)$. In both groups of infected animals the SI of T-lymphocytes decreased on week 2 p.i., which is the period important for the parasite establishment. After the short-time increase (week 4 p.i.) the T-cell proliferative activity remained low within the whole time of the experiment. ABCD therapy of

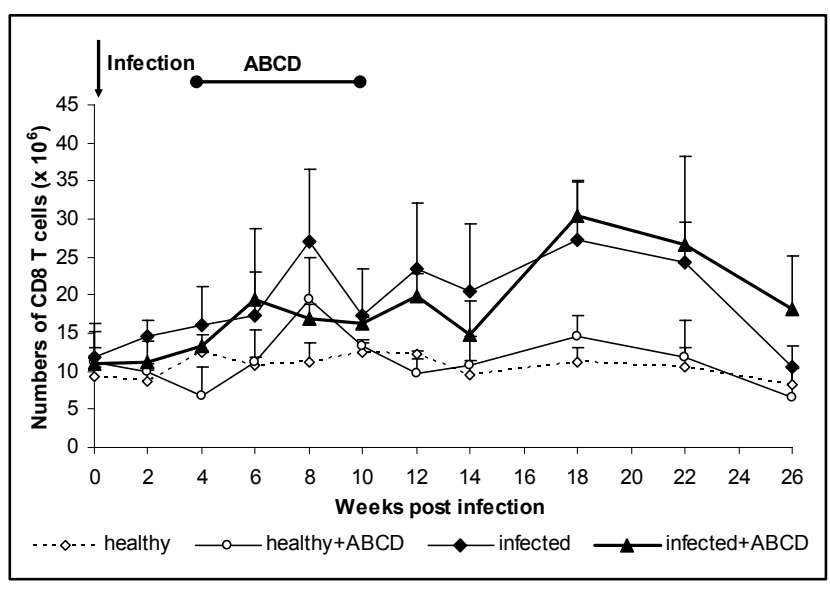

Fig. 4. Number of spleen CD8 T cells in mice infected with $E$. multilocularis and after ABCD therapy. Data for each time-point are expressed as mean value \pm S.D. $(n=3)$

the infected group did not restore the inhibition of $\mathrm{T}$ cell proliferation caused by the parasite.

There were no significant differences in the B cell proliferative response to nonspecific mitogen lipopolysaccharide (LPS) between the control group (uninfected and untreated) and healthy mice treated with $\mathrm{ABCD}$, only a moderate increase was recorded during ABCD administration (from week 6 to 10) (Fig. 2). The proliferative activity of B lymphocytes in the infected group was nonsignificantly higher on week 6 p.i., in a period of the intensive metacestode proliferation and the formation of protoscolices. The significant $(\mathrm{P}<0.05 ; \mathrm{P}<0.01)$ increases in SI of $\mathrm{B}$ lymphocytes were found in infected mice with $\mathrm{ABCD}$ treatment from week 6 to 10 p.i. (2nd week after the beginning of ABCD application to the end of therapy) in comparison with infected untreated mice. 


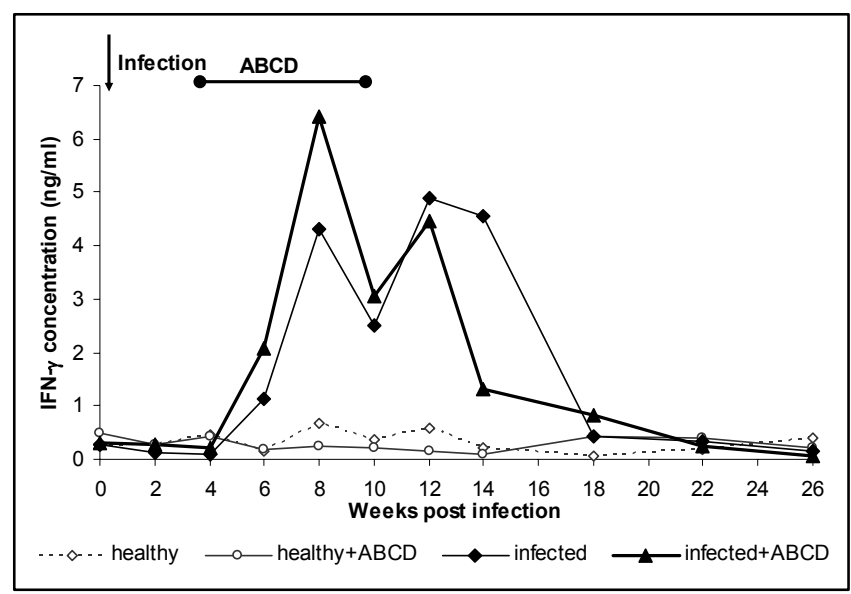

Fig. 5. Concentration of serum IFN- $\gamma$ cytokine in mice infected with E. multilocularis and after ABCD therapy. Data for each time-point are evaluated from pooled serum samples $(n=3)$ for each group

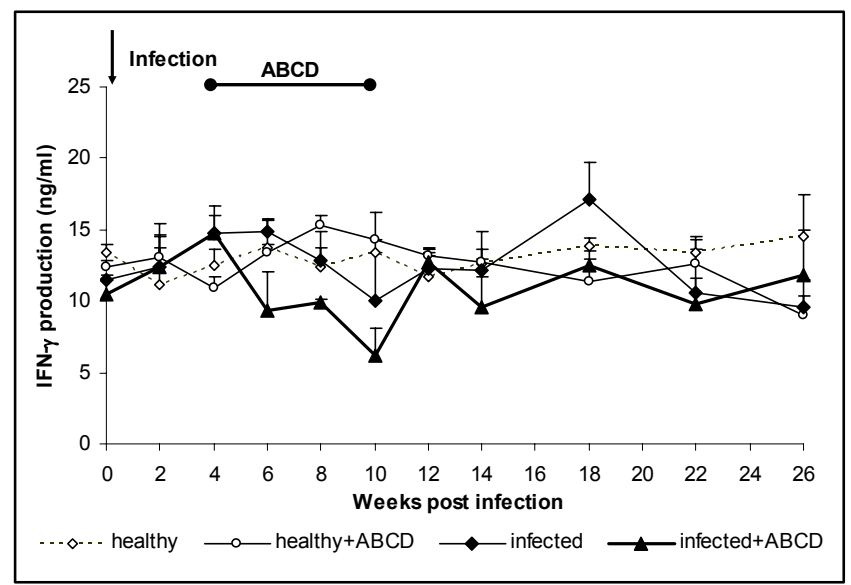

Fig. 6. IFN- $\gamma$ production in vitro by splenocytes from mice infected with E. multilocularis and after ABCD therapy. Data for each timepoint are expressed as mean value \pm S.D. $(n=3)$

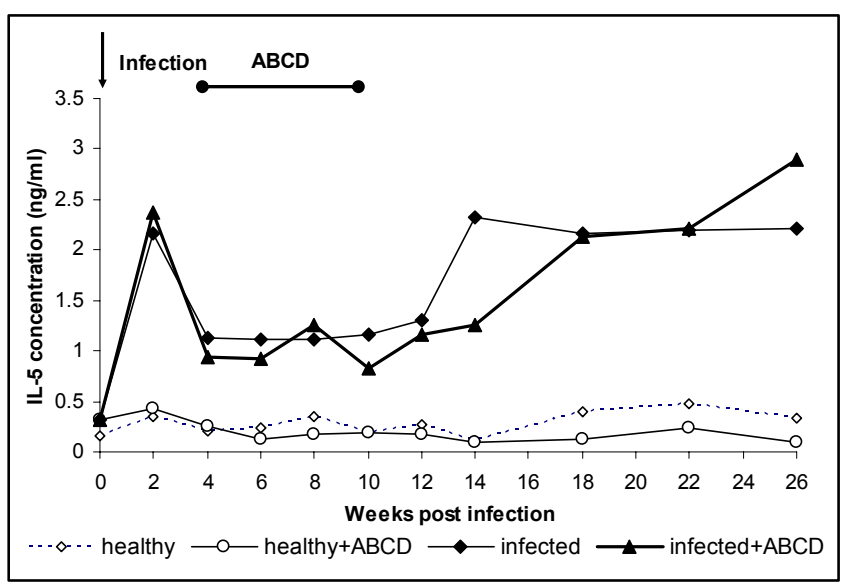

Fig. 7. Concentration of serum IL-5 cytokine in mice infected with E. multilocularis and after ABCD therapy. Data for each time-point are evaluated from pooled serum samples $(n=3)$ for each group

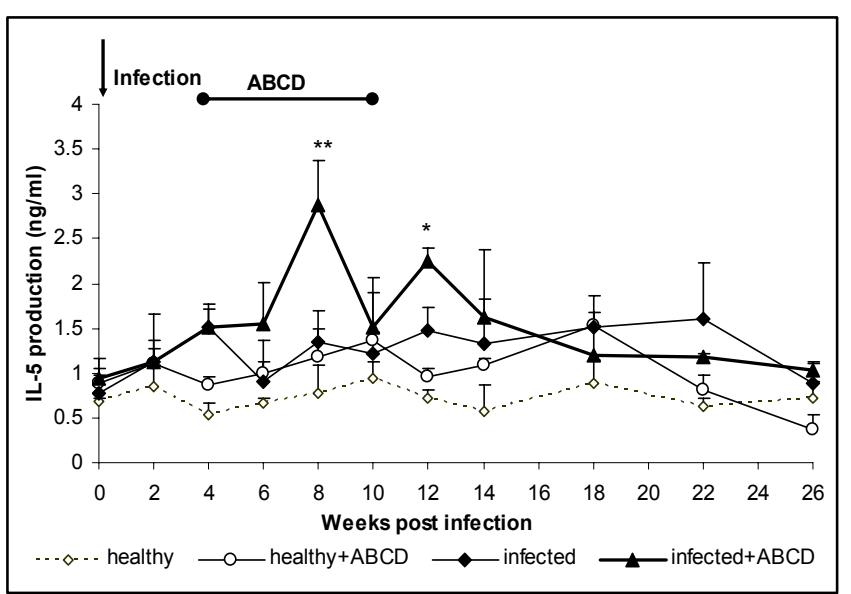

Fig. 8. IL-5 production in vitro by splenocytes from mice infected with E. multilocularis and after ABCD therapy. Data for each timepoint are expressed as mean value \pm S.D. $(n=3) . *(P<0.05)$, $* *(\mathrm{P}<0.01)$ significant differences between infected mice and infected mice with ABCD therapy

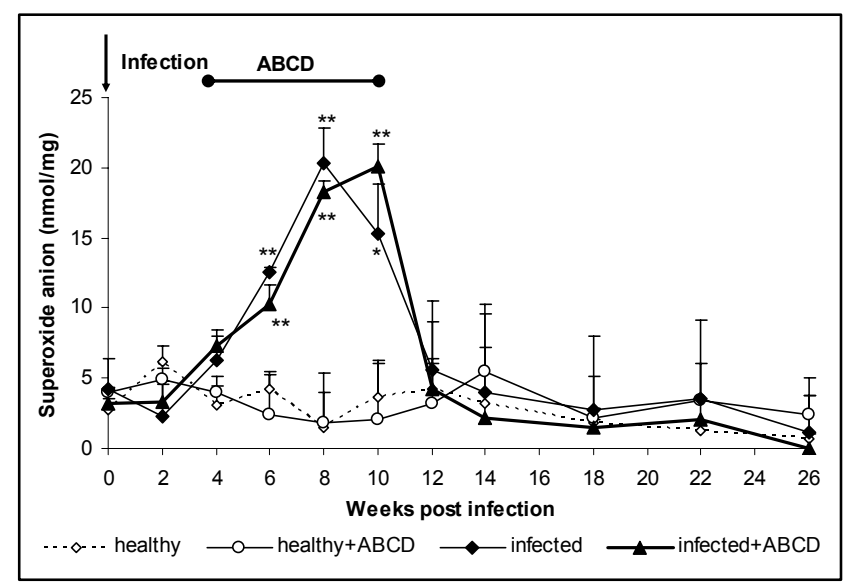

Fig. 9. Superoxide anion production in vitro by peritoneal macrophages from mice infected with $E$. multilocularis and after ABCD therapy. Data for each time-point are expressed as mean value \pm S.D. $(\mathrm{n}=3) . *(\mathrm{P}<0.05), * *(\mathrm{P}<0.01)$ significant differences between two uninfected groups (with and without $\mathrm{ABCD}$ therapy) and two infected groups (with and without $\mathrm{ABCD}$ therapy)

Number of $\mathrm{CD} 4+$ and $C D 8+$ expressing $T$ cells in spleen The functional status of the $\mathrm{T}$ cells was followed up through the expression of surface CD4+ and CD8+ antigens on the T cells. The number of CD4 T lymphocytes (Fig. 3) in spleen of E. multilocularis infected mice did not show considerable differences in comparison to control group. The significant rise in CD4 $\mathrm{T}$ cell number was recorded only in the infected and ABCD treated group on week 6 p.i. $(\mathrm{P}<0.05)$ in comparison with infected untreated group.

The number of CD8 T lymphocytes in spleen was not influenced by the course of therapy, even after the end of treatment (Fig. 4). The CD8 T cell subpopulation was moderately increased in both infected groups (with and without $\mathrm{ABCD}$ therapy) after week 6 p.i., however the changes were not significant. 
Concentration of IFN- $\gamma$ and $I L-5$ in serum and production in vitro

In order to examine the Th1/Th2 balance, cytokines IFN- $\gamma$ and IL-5 were monitored in the serum of mice and in the in vitro production of splenocytes stimulated with Con A. IFN- $\gamma$ serum level in infected mice with ABCD therapy was elevated only on week 8 p.i. in comparison with nontreated infected mice (Fig. 5). On contrary, the IFN- $\gamma$ production in vitro in the group of infected and ABCD treated mice was inhibited from week 6 to 10 p.i. (Fig. 6). A shortlasting and nonsignificant increase in the IFN- $\gamma$ production in vitro was found in healthy mice treated with ABCD on week 8 of the experiment. The serum IL-5 concentration was not influenced with ABCD therapy (Fig. 7). The IL-5 production in vitro was significantly stimulated in infected mice with ABCD therapy on weeks 8 and 12 p.i. $(\mathrm{P}<0.01 ; \mathrm{P}<0.05)$ in comparison with infected untreated mice (Fig. 8). In healthy mice, ABCD treatment also increased the IL-5 production, but with less intensity.

\section{Superoxide anion production}

The superoxide anion $\left(\mathrm{O}_{2}^{-}\right)$production (Fig. 9) was significantly $(\mathrm{P}<0.01)$ elevated from week 6 to 10 p.i. in both groups of infected mice (with and without ABCD therapy) in comparison to control group, then rapidly declined and remained stable at low values, similar to that seen in noninfected groups. There was no evidence of drug influencing the $\mathrm{O}_{2}^{-}$release from peritoneal macrophages in vitro.

\section{Discussion}

Amphocil (amphotericin B colloidal dispersion) was chosen in this work as an alternative therapy of alveolar echinococcosis to benzimidazoles. Amphotericin B (AMB) is the most effective drug for the treatment of visceral leishmaniasis (Murray, 2005) and it also acts against Trypanosoma (Yardley and Croft, 1999). Reuter et al. (2003a) demonstrated that $\mathrm{AMB}$ is highly effective against $E$. multilocularis metacestodes in vitro, but only with a parasitostatic effect. The mode of AMB action is attributed to the selective and irreversible binding to sterols in cell membranes (Abu-Salah, 1996). Membranes of E. multilocularis vesicles contain phospholipids and neutral lipids (Persat et al., 1990) therefore parasite cysts appeared to be an appropriate target for AMB, thus various metacestode components might have interacted with the drug. In our experiment the drug was administered intravenously and in a lipid form - ABCD (Amphocil) to reduce toxicity associated with $\mathrm{AMB}$. In vitro studies have shown that the drug in ABCD form is rapidly taken up by the organs - liver and spleen (Janknegt et al., 1992), and the liver is primarily affected by E. multilocularis. In addition, the liposomal structure of drug can enhance its anthelmintic effect by supporting the immune response to the parasite. The stimulative effect of liposome-entrapped drug on Th1 protective host immunity during E. multilocularis infection confirmed the results of Dvorožňáková et al. (2004).

The outcome of a treatment of alveolar echinococcosis might be affected by the immunological status of the host, because an establishment of immunosuppression of the host is the main aspect of the survival strategy of $E$. multilocularis (Gottstein et al., 2006; Vuitton et al., 2006). Many studies (Rigano et al., 1999; Borošková et al., 2003; Dvorožňáková et al., 2004) have demonstrated that antiparasitic albendazole therapy can modify cellular and humoral immunity in echinococcosis. The modulatory effect could be derived from the fact, that a drug induces direct morphological and structural changes of parasite cysts walls and protoscoleces (Pérez-Serrano et al., 1997), which lead to the revealing of normally unexposed structural antigens, which are presented to $\mathrm{T}$ lymphocytes. This results in the induction of a Th2 response (chronic antigen stimulation) or a Th1 response (small parasitic lesions or reduced antigen output/recognition) (Abbas et al., 1996).

AMB have been tested in various animal models which differ in many aspects, such as the type of animal, the immunological status of the animal (immunocompetent versus immunosuppressed), the pathogen, the route of challenge and the dose, and the therapeutic regime. The reports concerning immunomodulatory effects of AMB are contradictory, which could be also explained by the fact that AMB dose dependent toxicity for mammalian cell precludes the demonstration any immunostimulatory effects (Brajtburg \& Bolard, 1996).

T-lymphocytes play a major role in the control of immune response in E. multilocularis infected intermediate host organism. Our results did not confirm the expected T-cell activating effect of ABCD in mice with alveolar echinococcosis. The drug stimulated T-lymphocyte proliferation only in healthy mice. ABCD therapy caused an increase in the proliferative response during the drug administration, from week 6 to 10 p.i. But ABCD therapy did not induce any important changes in T-cell proliferation in infected animals. The suppression of the proliferative activity of $\mathrm{T}$ lymphocytes caused by Echinococcus infection might have been stronger than the stimulative action of ABCD observed in immunocompetent healthy mice. Similar results were recorded by Zhang et al. (2006) with ABCD, which did not cause any biologically significant or dose-related changes in B- or T- cell responses to mitogens. The ability to generate a primary antibody response to T-cell dependent antigen was also unimpaired (Zhang et al., 2006). On contrary, ABCD therapy of murine alveolar echinococcosis in our experiment caused significant stimulation of B-lymphocytes from week 6 to 10 p.i. This result is in agreement with Stein et al. (1987) in relation to the immunostimulative impact of AMB on murine B lymphocytes in vitro. However, nonliposomal AMB therapy of leishmaniasis (Ehrenfreund-Kleinman et al., 2005) did not altered the T lymphocyte proliferative response, as in our work, but inhibited the stimulation of B lymphocytes. Schindler et al. (1993) found that a high concentration of conventional AMB (Fungizone) inhibited mouse splenocyte proliferation, whereas high concentration of liposomal AMB (AmBisome) had no effect on the immunologic activity of splenocytes, this supports the safety of liposomised form of 
AMB, which does not depress further an already parasitedepressed immune system.

The functional status of $\mathrm{T}$ cells is closely related to two of their most important subpopulations (CD4, CD8) in celullar response to E. multilocularis infection. The numbers of CD4 splenocytes in infected and ABCD treated mice in our work were significantly increased, but only for a short time (on week 6 p.i.). The long-term increase in CD4 cells after AMB therapy could contribute to making an anti-parasite defence (the periparasitic granuloma formation) more effective. Afterward the decrease of CD4 cell subpopulation (from week12 to 26 p.i.) was observed in infected mice regardless of ABCD therapy. The changes of CD4 or CD8 T cell subpopulation after AMB therapy are not mentioned in literature. Only Geginat et al. (1999) observed a strong suppressive effect of AMB on the function of CD8 $\mathrm{T}$ cells in immunity to Listeria monocytogenes in vitro and in vivo. In our work with alveolar echinococcosis of mice, the CD8 T cell subpopulation was not influenced by ABCD therapy. According to Kizaki et al. (1991) in case of the splenic CD8 subpopulation in alveolar echinococcosis there are mostly $\mathrm{T}$ suppressor cells with a low density of the CD8 antigen. Therefore we deduce, that $\mathrm{ABCD}$ therapy moderately supported the suppressive regulation of the immune response.

Active alveolar echinococcosis is associated with Th2 profile - overproduction of IL-5 and IL-10 and insufficient IFN- $\gamma$ production (Vuitton, 1999). Despite of ABCD therapy in our work, there has been a tendency of Th1/Th2 proportion shift to Th2 response. The in vitro production of Th1 cytokine IFN- $\gamma$ was inhibited from week 6 to 10 p.i. On the other side, the in vitro IL-5 (Th2 cytokine) synthesis was elevated from week 6 to 12 p.i. Increased B-cell activation (weeks 6-10 p.i.) also indicates Th2 activation. The increased level of serum IFN- $\gamma$ in infected and ABCD treated mice was recorded only on week 8 p.i., i.e. in the middle of the therapy, which did not manage to overturn the Th2 response - advantageous for the metacestode's survival. The concentration of IL-5 in serum was not affected by ABCD therapy.

In vitro studies with lipid AMB formulations (Simitsopoulou et al., 2005) showed a trend of inflammatory gene upregulation mRNA cytokine profile (cytokine IL-1 $\beta$ ), but have also demonstrated that various AMB formulations differentially affect gene expression and release of proand anti-inflammatory cytokines, this may explain the differences in the modulation of the host immune response. Sau et al. (2003) recorded the stimulation of transcription and production of proinflammatory cytokines by cells of the immune system after AMB treatment. Nonliposomal AMB therapy of leishmaniasis (Ehrenfreund-Kleinman et $a l ., 2005)$ increased TNF- $\alpha$ release from mouse peritoneal macrophages and human monocytes, but had no effect on IFN- $\gamma$ and NO release. Rama-Iniguez et al. (2006), who used AMB formulated in microspheres from human serum albumin (AMB-HSA) for treatment of leishmaniasis in hamsters, found that high doses of AMB-HSA $(40 \mathrm{mg} / \mathrm{kg})$ caused deactivation of the anti-inflammatory cytokine
TGF- $\beta$, which in turn results in an up-regulation of the Th1 cytokines IFN- $\gamma$ and TNF- $\alpha$. The dose of $10 \mathrm{mg} / \mathrm{kg}$ b.w. in our experiment under in vivo conditions might have been low for this positive immunomodulative effect of AMB. Macrophages have a key role in effector phase of immune response to E. multilocularis through oxygen derivaties and NO production (Vuitton, 2003) which provide for the protoscoleces destruction (Reuben \& Tanner, 1983). AMB supports the respirative burst in macrophages (Wolf \& Massof, 1990). AMB autooxidation and formation of free radicals may have different effects on cells. The positive effect on cell stimulation is probably a result of AMB's ability to modulate the endogenous level of cell resistance to oxidative stress (Brajtburg et al., 1990). In our experiment, the increased superoxide anion production was recorded in the phase of established infection (weeks $6-10$ p.i.), but no significant changes in the ABCD treated group were observed in comparison to infected mice without therapy. The macrophage stimulation factors are released from B cells by the antigens from destroyed Echinococcus protoscoleces (Šoltýs et al., 1999) and we recorded a nonspecific stimulation of the B proliferation after ABCD therapy and a high generation of superoxide anion from peritoneal macrophages at the same time (weeks $6-10$ p.i.). IFN- $\gamma$ is one of the cytokines which most influences the macrophage energetic system (Resch, 1999), but IFN- $\gamma$ serum level after ABCD therapy in our work was increased for very short time on week 8 p.i., and in splenocytes we observed a down-regulation in its production in vitro.

Possible dose-dependent toxicity might have abolished the positive therapeutic effect of lipid drug formulation in infected mice and supported the undesirable immunosupression caused by the parasite. The distribution of AMB differs widely between organs, and the highest AMB concentrations are reached in the liver (Christiansen et al., 1985) with the potential to alter hepatic cellular integrity. Inselmann et al. (2000) found that liposomal AMB does not influence hepatic metabolic function in contrast to conventional $\mathrm{AMB}$, which decreases hepatic propafenone metabolism. Therefore we assume a nontoxic effect of our AMB colloidal dispersion as used in our experiment.

Althought a positive influence of AMB on Echinococcus metacestode growth in vitro and also in 2 human cases of active $\mathrm{AE}$ (not responding to conventional ABZ therapy) were recorded (Reuter et al., 2003a,b), the results of our experiment did not confirm any metacestode growth restriction in E. multilocularis infected mice after ABCD therapy. Moreover, no significant immunostimulative effect of the drug was observed during the course of the infection. We suppose that the slow release of free AMB from the lipid complexes could be a cause of the failure of our ABCD therapy for murine alveolar echinococcosis. The severity of the infection was increased, when there was a decrease in the susceptibility of the metacestode to $\mathrm{ABCD}$, as has been observed in protozoal and bacterial infections (Gilbert et al., 1992; Karyotakis \& Anaissie, 1994).

Our experimental ABCD therapy with the intention of halt- 
ing the larval development of E. multilocularis in a murine host failed. However, it could be caused by an inappropriate choice of the drug formulation, its dose and the therapeutic regime. Also the high infective dose of E. multilocularis and starting the therapy in a progressive echinococcosis could contribute to this failure. We did not find any major immunomodulation or even immunorestoration of the parasite immunosuppressed mice, only small indications appeared in the middle of ABCD therapy, but this stimulative trend was cancelled in the next course of the infection.

\section{Acknowledgement}

This work was supported by Science and Technology Assistance Agency under the contract No. APVT-51-010704 and by grant VEGA 2/7186/27.

\section{References}

Abbas, A. K., Murphy, K. M., Sher, A. (1996): Functional diversity of helper T lymphocytes. Nature, 383: 787 793

ABU-SAlaH, K. M. (1996): Amphotericin B: an update. Brit. J. Biomed. Sci., 53: $122-133$

AmmanN, R. W., ECKERT, J. (1996): Cestodes: Echinococcus. Gastroenter. Clin. North Am., 25: 655 - 689

BorošKovÁ, Z., DvorožŇÁKovÁ, E., ŠEvČíKOVÁ, Z. (2003): Cellular immune reactions of mice with alveolar echinococcosis after albendazole therapy. Helminthologia, 40: $187-194$

BrajtburG, J., Bolard, J. (1996): Carrier effects on biological activity of amphotericin B. Clin. Microb. Rev., 9: $512-531$

Brajtburg, J., Powderly, W. G., Kobayashi, G. S., MEDOFF, G. (1990): Amphotericin B: current understanding of mechanisms of action. Antimicrob. Agents Chemother., 34: $183-188$

Bresson-Hadni, S., Liance, A., Meyer, J. P., Houin, R., BREsSon, J. L., VuitTon, D. A. (1990): Cellular immunity in experimental Echinococcus multilocularis infection. II. Sequental and comparative phenotypic study of the periparasitic mononuclear cells in resistant and sensitive mice. Clin. Exp. Immunol., 82: 378 - 383

Capece, B. P., Navarro, M., Arcalis, T., Castells, G., Toribio, L., Perez, F., Carretero, A., Ruberte, J., ArBOIX, M., CRISTOFOL, C. (2003): Albendazole sulphoxide enantiomers in pregnant rats' embryo concentrations and developmental toxicity. Vet. J., 165: $266-275$

Christiansen, K. J., Bernard, E. M., Gold, J. W. M., ARMSTRONG, D. (1985): Distribution and activity of amphotericin B in humans. J. Infect. Dis., 152: $1037-1043$

Clements, J. S. JR., PeAcock, J. E. JR. (1990): Amphotericin B revisited: reassessment of toxicity. Amer. J. Med., 88: $22-27$

Clemons, K. V., Sobel, R. A., Williams, P. L., Stevens, D. A. (2001): Comparative toxicities and pharmacokinetics of intrathecal lipid (amphotericin B colloidal dispersion) and conventional deoxycholate formulations of amphotericin B in rabbits. Antimicrob. Agents Chemother., 45: $612-615$

DVOroŽŇÁKOvÁ, E., HrČKOVÁ, G., BOROŠKOVÁ, Z., VELEBNÝ, S., DUBINSKÝ, P. (2004): Effect of treatment with free and liposomized albendazole on selected immunological parameters and cyst growth in mice infected with Echinococcus multilocularis. Parasitol. Int., 53: 315 - 325 Ehrenfreund-Kleinman, T., Domb, A. J., JafFe, C. L., Nasereddin, A., Leshem, B., Golenser, J. (2005): The effect of amphotericin b derivatives on Leishmania and immune functions. J. Parasitol., 91: $158-163$

Ellis, D. (2002): Amphotericin B: spectrum and resistance. J. Antimicrob. Chemother., 49: 7 - 10

Emery, I., Liance, M., Deriaud, E., Vuitton, D. A., Houin, E., LECLERC, C. (1996): Characterization of T-cell immune responses of Echinococcus multilocularis-infected. Parasite. Immunol., 18: 463 - 472

Geginat, G., Kretschmar, M., WAlter, S., JunKer, D., HOF, H., NiCHTERLEIN, T. (1999): Suppression of acquired immunity against Listeria monocytogenes by amphotericin B-mediated inhibition of CD8 T cell function. J. Infect. Dis., 180: 1186 - 1194

Gilbert, B. E., WydE, P. R., Willson, S. Z. (1992): Aerosolized liposomal amphotericin B liposomes for treatment of pulmonary and systematic Cryptococcus neoformans infections in mice. Antimicrob. Agents Chemother., 36: $1466-1471$

Gottstein, B., HaAg, K., Walker, M., Matsumoto, J., MEJRI, N., HEMPHILL, A. (2006): Molecular survival strategies of Echinococcus multilocularis in the murine host. Parasitol. Int., 55: S45 - S49

Hann, I. M., PRentice, H. G. (2001): Lipid-based amphotericin B: a review of the last 10 years of use. Int. J. Antimicrob. Agents, 17: $161-169$

HEATH, D. D. (1995): Immunology of Echinococcus infection. In THOMPSON, R. C. A., LYMBERY, A. J. (Eds): Echinococcus and hydatid disease. CAB INTERNATIONAL, Wallingford, UK: 183 - 199

HiEMENZ, J. W., WALSH, T. J. (1996): Lipid formulations of amphotericin B: recent progress and future directions. Clin. Infect. Dis., 22: S133 - S144

HRČKOVÁ, G., VELEBNÝ, S. (1997): Effect of praziquantel and liposome-incorporated praziquantel on peritoneal macrophage activation in mice infected with Mesocestoides corti tetrathyridia (Cestoda). Parasitology, 114: 475 - 482 InselmanN, G., VolkmanN A., HeIDEMANN, H. T. (2000): Comparison of the effects of liposomal amphotericin $\mathrm{B}$ and conventional amphotericin B on propafenone metabolism and hepatic cztochrome P.450 in rats. Antimicrob. Agents Chemother., 44:131 - 133

JANknegt, R., DeMARIE, S., BAKKer-WoudenberG, I. A., Crommelin D. J. (1992): Liposomal and lipid formulations of amphotericin B. Clin. Pharmacokinet., 23: $279-$ 291

Joly, V., FArinotti, R., SAint-Julien, L., ChÉron, M., CARBon, C., ZENI, P. (1994): In vitro renal toxicity and in vivo therapeutic efficacy in experimental murine crypto- 
coccosis of amphotericin B (Fungizone) associated with intralipid. Antimicrob. Agents Chemother., 38: 177 - 183

KARYOTAKIS, N. C., ANAissie, E. J. (1994): Efficacy of escalating doses of liposomal amphotericin B (AmBisome) against hematogenous Candida lusitaniae and Candida krusei infection in neutropenic mice. Antimicrob. Agents Chemother., 38: 2660 - 2662

Kilwinski, J., Jenne, L., Jellen-Ritter, A., RAdloff, P., FLICK, W., KERN, P. (1999): T lymphocyte cytokine profile at a single cell level in alveolar echinococcosis. Cytokine, 11: $373-381$

Kizaki, T., Kobayashi, S., Ogasawara, K., Day, N. K., GoOD, R. A., ONOE, K. (1991): Immune suppression induced by protoscoleces of E. multilocularis in mice. Evidence for the presence of CD ${ }^{\text {dull }}$ suppressor cells in spleens of mice intraperitoneally infected with E. multilocularis. J. Immunol., 147: 1659 - 1666

Manfras, B. J., Reuter, S., Wendland, T., Boehm, B. O., KERN, P. (2004): Impeded Th1 CD4 memory T cell generation in chronic-persisting liver infection with Echinococcus multilocularis. Int. Immunol., 16: 43 - 50

Murray, H. W. (2005): Prevention of relapse after chemotherapy in a chronic intracellular infection: mechanisms in experimental visceral leishmaniasis. J. Immunol., 174: $4916-4923$

Pagé, M., Bajaouni, N., Ciqo-Mars, B., Lemieux, P. (1988): Optimization the tetrazolium based colorimetric assay for the measurement of cell number and cytotoxicity. Int. J. Immunopharmacol., 10: 785 - 793

Pérez-Serrano, J., Denegri, G., Casado, N., RodríGUEZ-CAABEIRO, F. (1997): In vivo effect of oral albendazole and albendazole sulphoxide on development of secondary Echinococcosis in mice. Int. J. Parasitol., 27: $1341-1345$

Persat, F., Bouhours, J. F., Mojon, M., Petavy, A. F. (1990): Analysis of the monohexosylceramide fraction of Echinococcus multilocularis metacestodes. Mol. Biochem. Parasitol., 41: $1-6$

Rama-Iniguez, S., DeA-AyUela, M. A., SANChEZ-BrUnete J. A., Torrado, J. J., Alunda, J. M., Bolas-FerNANDEZ, F. (2006): Real-time reverse transcription-PCR quantification of cytokine mRNA expression in golden Syrian hamster infected with Leishmania infantum and treated with a new amphotericin B formulation. Antimicrob. Agents Chemother., 50: 1195 - 1201

RESCH, K. (1999): Cytokines. In NiJKAMP F. P., PARnHAM, M. J. (Eds): Principles of Immunopharmacology. Birghäuser Verlag, Basel, Boston, Berlin: $53-81$

Reuben, J. M, TANNER, C. E. (1983): Protection against experimental echinococcosis by non-specifically stimulated peritoneal cells. Parasite Immunol., 5: 61 - 66

Reuter, S., Jensen, B., Buttenschoen, K., Kratzer, W., KERN, P. (2000): Benzimidazoles in the treatment of alveolar echinococcosis: a comparative study and review of the literature. J. Antimicrob. Chemother., 46: 451 - 456 Reuter, S., Merkle, M., Brehm, K., Kern, P., Manfras, B. (2003a): Effect of amphotericin B on larval growth of Echinococcus multilocularis. Antimicrob. Agents Chemo- ther., 47: $620-625$

Reuter, S., Buck, A., Grebe, O., Nussle-Kugele, K., KERN, P., MANFRAS, B. J. (2003b): Salvage treatment with amphotericin B in progressive human alveolar echinococcosis. Antimicrob. Agents Chemother., 47: 3586 - 3591 Rigano, R., Profumo, E., Buttari, B., Teggi, A., SiraCUSANO, A. (1999): Cytokine gene expression in peripheral blood mononuclear cells (PBMC) from patients with pharmacologically treated cystic echinococcosis. Clin. Exp. Immunol., 118: 95 - 101

Sau, K., Mambula, S. S., Latz, E., Henneke, P., GolenBOCK, D. T., LEVITZ, S. M. (2003): The antifungal drug amphotericin B promotes inflammatory cytokine release by a Toll-like receptor- and CD14-dependent mechanism. J. Biol. Chem., 278: $37561-37568$

Schantz, P. M. (2002): Progress and challenges in biology, treatment and control of echinococcosis. Abstracts ICOPA X, Vancouver, Canada: 243

SChindler, J. J., WARREN, R. P., Allen, S. D., JACKSON, M. K. (1993): Immunological effects of amphotericin B and liposomal amphotericin B on splenocytes from immune-normal and compromised mice. Antimicrob. Agents Chemother, 37: 2716 - 2721

Simitsopoulou, M., Roilides, E., Dotis, J., DalakiouRIDOU, M., DudKova, A. F., ANDrEAdOU, E., WALSH, T. J. (2005): Differential expression of cytokines and chemokines in human monocytes induced by lipid formulations of amphotericin B. Antimicrob. Agents Chemother., 49: $1397-1403$

Stein, S. H., Little, J. R., Little, K. D. (1987): Parallel inheritance of tissue catalase activity and immunostimulatory action of amphotericin B in inbred mouse strains. Cell. Immunol., 105: $99-109$

Sturm, D., Menzel, J., Gottstein, B., Kern, P. (1995): Interleukin-5 is the predominant cytokine produced by peripheral blood mononuclear cells in alveolar echinococcosis. Infect. Immun., 63: 1688 - 1697

ŠolTÝs, J., QUINN, M. T. (1999): Modulation of endotoxin- and enterotoxin-induced cytokine release by in vivo treatment with $\beta$-(1,6)-branched $\beta$-(1,3)-glucan. Infect. Immun., 67: $244-252$

ŠOlTÝs, J., TuRČEKOVÁ, L., RYCKE, DE P. H. (1999): The effect Echinococcus hydatid cyst fluid and protoscoleces on mouse peritoneal macrophages and spleen lymphocytes. Helminthologia, 36: 25 - 30

THOMPSON, R. C. A. (1995): Biology and systematics of Echinococcus. In THOMPSON, R. C. A., LYMBERY, A. J. (Eds): Echinococcus and hydatid disease. CAB INTERNATIONAL, Wallingford, UK: $1-50$

VuitTON, D. A. (2003): The ambiguous role of immunity in Echinococcosis: protection of the host or of the parasite? Acta. Trop., 85: $119-132$

Vuitton, D. A., Zhang, S. L., YAnG, Y., Godot, V., Beurton, I., Mantion, G., Bresson-Hadni, S. (2006): Survival strategy of Echinococcus multilocularis in the human host. Parasitol. Int., 55: S51 - S55

VuitTon, D. A. (1999): New trends in the treatment of echinococcosis. Helminthologia, 36: $167-170$ 
Wolf, J. E., MASSOF, S. E. (1990): In vivo activation of macrophage oxidative burst activity by cytokines and amphotericin B. Infect. Immun., 58:1296 - 1300

YARDLEY, V., CROFT, S. L. (1999): In vitro and in vivo activity of amphotericin B-lipid formulations against experimental Trypanosoma cruzi infections. Am. J. Trop. Med.

RECEIVED FEBRUARY 15, 2007
Hyg., 61: $193-197$

Zhang, Z., Lipman, J. M., Diener, R. M., Thomas, P. (2006): Comparative immunotoxicity evaluation of amphotericin B and ABELCET, an amphotericin B lipid complex (ABLC). Int. J. Toxicol., 25: 487 - 492

ACCEPTED MARCH 20, 2007 